\section{Evidence-based practice in acute ophthalmology}

\begin{abstract}
Aim To study the overall level of evidencebased practice in an accident and emergency eye unit in the UK and evaluate the extent of evidence-based practice by ophthalmologists and nurse practitioners (NPs).

Methods The case notes of all new patients attending our accident and emergency department for a period of 1 week were reviewed prospectively. For each case, the diagnosis at presentation and its intervention was ascertained. A literature search using Medline and Cochrane library was performed to assess the level of evidence provided for each diagnosis-intervention pair. Each diagnosisintervention pair was evaluated and graded to assess the best level of evidence provided. Results A total of 474 new patients attended the eye casualty during the study period. No diagnosis was made in 27 cases and they were excluded from the analysis. Out of 447
\end{abstract} patients, $308(68.9 \%)$ cases were managed by NPs and $139(31.1 \%)$ by doctors. A total of 294 $\mathbf{6 5 . 8 \% )}$ patient interventions were based on evidence from systematic reviews, metaanalysis and randomised-controlled trials, of which 223 were managed by NPs and 71 by ophthalmologists. This difference was statistically significant with $P<0.001$. One hundred and seven $(23.9 \%)$ interventions were supported by evidence from prospective and retrospective trials.

Conclusion This study demonstrated that two-thirds of interventions were based on the highest level of evidence and was comparable to studies performed in other specialities. It also highlights the advanced role of trained NPs in acute ophthalmology. Eye (2007) 21, 976-983; doi:10.1038/sj.eye.6702374; published online 28 April 2006

Keywords: evidence-based medicine; acute ophthalmology; nurse practitioners

\section{Introduction}

Evidence-based medicine is the 'conscientious, explicit, and judicious use of current best evidence in making decisions about care of individual patients'. ${ }^{1}$ The philosophical origin of evidence-based medicine extends back to mid-19th century and earlier, ${ }^{1}$ but has gained considerable momentum only in the last decade. There is an increasing demand that medical practice should no longer be based on hypothetical thinking but rather on scientific validation. The Oxford centre for evidencebased medicine has developed a grading scheme depending on the quality of scientific evidence. According to it, depending on the validity of evidence, the systematic review of randomised-controlled trials and randomisedcontrolled trials form the highest level of evidence, that is, level 1 , and case reports, and expert opinion form the lowest level, that is, levels 4 and 5, respectively. ${ }^{2}$

In 1991, it was suggested that only $15 \%$ of medical interventions are supported by solid scientific evidence. ${ }^{3}$ Since then various studies have been conducted in different specialities to refute this claim. Ellis et al ${ }^{4}$ studied whether in-patient general medicine is evidence based. In their retrospective study they found that $82 \%$ of patients received evidence-based interventions. Jemec et $a l^{5}$ found that threequarters of dermatologic outpatient therapy is based on scientific evidence and Howes et al concluded that in-patient general surgery is evidence based, but the proportion of surgical treatments supported by randomised-controlled trials is much smaller than that found in general medicine. In 2003, a clinical audit was conducted at Hong Kong eye hospital to determine the proportion of evidence-based interventions in their emergency unit. The audit found that $42.9 \%$ of interventions were based on evidence from systematic reviews, metaanalysis, or randomised-controlled trials. ${ }^{7}$ 
Wolverhampton and Midland Counties Eye Infirmary is a large district general hospital serving population of approximately 1 million. Average annual attendance for the ophthalmic Accident and Emergency department is 24-25000. A triage system was introduced in 1998 to tackle the ever increasing workload. According to this, the patients are prioritised depending on the acuteness and severity of the presenting condition. All grades of staff including Ophthalmic trained nurse practitioners (NPs), junior and senior Ophthalmologists are involved in patient care. Ophthalmic trained NPs on an average diagnose and manage about two-third of the cases.

We conducted a prospective study to evaluate the proportion of ophthalmic interventions that are evidence based in an ophthalmic accident and emergency setting. To the best of our knowledge, there has been no similar study conducted in acute ophthalmology in the UK.

\section{Methods}

In July 2003, for a period of 1 week, the charts of all the new patients attending our accident and emergency department were prospectively retrieved. As this was a prospective, observational study in consecutive patients with no major exclusion criteria no ethical approval was sought. To avoid bias, the NPs and the doctors on duty during the time were kept unaware of the study and the three investigators did not have any duty in the accident and emergency department during this time period. Charts of all the new attendants were collected at the end of the day and data regarding patients' characteristics and the examining medical or nursing staff was taken in a standard proforma. For each new case, a primary diagnosis at presentation and primary intervention was identified individually by each investigator. Primary diagnosis was defined as the condition with which patient presented to the accident and emergency department and primary intervention was the single most relevant intervention for its management. The cases in which no diagnosis was derived were excluded from the analysis. A corresponding literature search for each diagnosis-intervention pair using Medline from 1966 to October 2004 and Cochrane library was carried out to assess the level of evidence provided. The search was limited to English language. The evidence obtained was verified by two investigators separately. In case of discrepancy, a common consensus was reached following discussion. The evidence obtained was then graded into five hierarchical categories as described by Kingston et al ${ }^{8}$ (Table 1). Accordingly, systematic review was graded as level 1 evidence and retrospective study as level 5 evidence. This methodology was identical to the study by Lai et al. ${ }^{7}$ Unlike the levels of evidence described by Oxford centre of evidence-based medicine, case reports
Table 1 Levels of evidence according to Kingston et $a l^{8}$ $(n=447)$

\begin{tabular}{llc}
\hline Level & Study design & No. of patients (\%) \\
\hline 1 & Systematic review & $80(17.9)$ \\
2 & Meta-analysis & $33(7.4)$ \\
3 & Randomised-controlled trial & $181(40.5)$ \\
4 & Prospective study & $65(14.5)$ \\
5 & Retrospective study & $42(9.4)$ \\
None & No evidence or evidence opposed & $46(10.3)$ \\
& the intervention & \\
\hline
\end{tabular}

and expert opinion were not considered in this hierarchy of evidence.

The number (\%) of patients managed by ophthalmologists and ophthalmic NPs were derived and the number $(\%)$ of patient intervention in each group supported by evidence levels 1, 2, and 3 were calculated. Percentages were calculated using the number of patients studied as denominator. $\chi^{2}$ test was performed to see the difference between the proportion of interventions based on highest level of evidence between the two groups (Ophthalmic trained NPs and ophthalmologists).

\section{Results}

A total of 474 patients attended our accident and emergency department during the study period. A total of 27 patients were excluded from the analysis as no diagnosis was derived. Out of 447 patients, 278 (58.6\%) were male and $196(41.4 \%)$ were female. The age ranged from 4 weeks to 93 years. A total of 308 (68.9\%) patients were managed by ophthalmic trained NPs and 139 (31.1\%) by junior and senior ophthalmologists.

Altogether 80 primary diagnosis-intervention pairs were made. Figure 1 shows the number of patient interventions supported by each level of evidence and individual bar in each category showing whether they were managed by a NP, or an ophthalmologist.

A total of 294 (65.8\%) of patient interventions and 32 diagnosis-intervention pairs were based on evidence from systematic reviews, meta-analysis, and randomisedcontrolled trials (Tables 2 and 3). Out of 308 patients managed by NPs, 223 (72.4\%) interventions were based on evidence levels 1, 2, and 3 and out of 139 patients managed by ophthalmologists, $71(51.1 \%)$ interventions were based on evidence levels 1, 2, and 3. This difference was statistically significant with $P<0.001$. Out of 32 diagnosisintervention pairs based on highest level of evidence, four were exclusively managed by NPs and the remaining by ophthalmologists. A total of 107 (23.9\%) patient interventions were based on prospective and retrospective trials (Tables 4 and 5). Overall, $89.7 \%$ of patient interventions were based on some scientific evidence. 


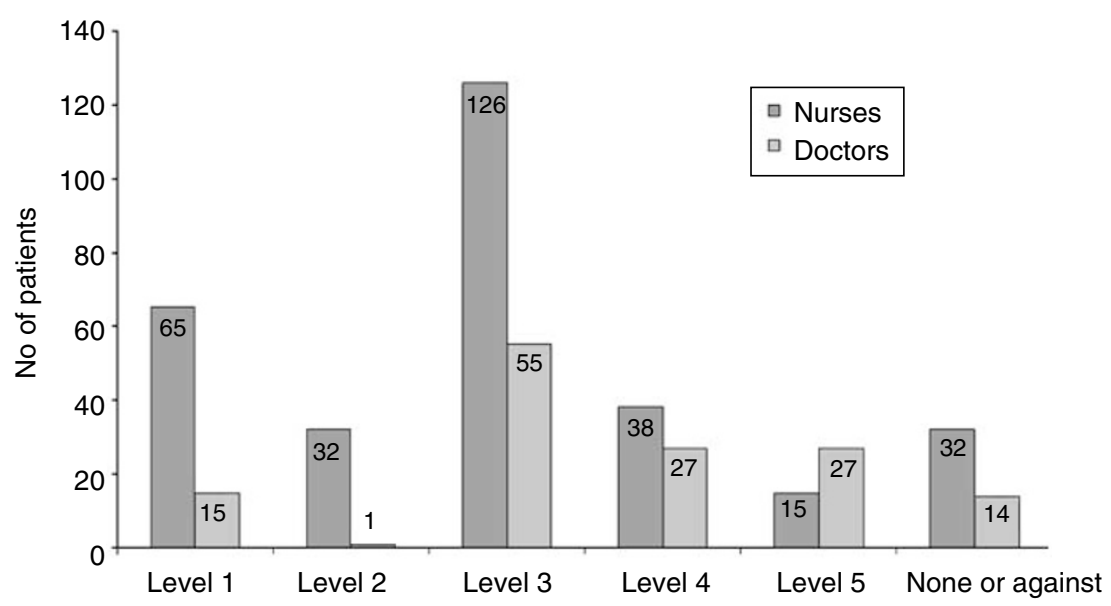

Figure 1 Number of patient inventions based on each level of evidence (Kingston et al, ${ }^{8} n=447$ ).

Table 2 Interventions based on systematic reviews or meta-analysis $(n=113)$

\begin{tabular}{|c|c|c|c|c|c|}
\hline Primary diagnosis & Primary intervention & $\begin{array}{l}\text { Total no. of } \\
\text { patients }\end{array}$ & $\begin{array}{l}\text { No. of patients } \\
\text { managed by NPs }\end{array}$ & $\begin{array}{l}\text { No. of patients } \\
\text { managed by } \\
\text { doctors }\end{array}$ & Reference \\
\hline $\begin{array}{l}\text { Presumed bacterial } \\
\text { conjunctivitis }\end{array}$ & Topical broad spectrum antibiotics & 69 & 65 & 4 & 9 \\
\hline Corneal abrasion & Topical antibiotics, no patching & 32 & 32 & 0 & 10 \\
\hline Dendritic ulcer & Topical acyclovir & 6 & 0 & 6 & 11 \\
\hline Senile cataract & Phacoemulsification cataract extraction & 2 & 0 & 2 & 12 \\
\hline $\begin{array}{l}\text { Asymptomatic, round } \\
\text { retinal hole }\end{array}$ & No treatment & 1 & 0 & 1 & 13 \\
\hline $\begin{array}{l}\text { Asymptomatic lattice } \\
\text { degeneration }\end{array}$ & No treatment & 1 & 0 & 1 & 13 \\
\hline $\begin{array}{l}\text { Neovascular glaucoma } \\
\text { sec to CRVO }\end{array}$ & $\begin{array}{l}\text { Maximum medical therapy }+ \text { argon laser } \\
\text { panretinal photocoagulation }\end{array}$ & 1 & 0 & 1 & 14 \\
\hline Choroidal melanoma & Ruthenium plaque & 1 & 0 & 1 & 15 \\
\hline
\end{tabular}

A total of $24(5.4 \%)$ patient interventions were against the evidence and there was no evidence for $22(4.9 \%)$ interventions (Tables 6 and 7). Thirty two (10.4\%) of patients managed by NPs were against evidence or had no evidence as opposed to $14(10.1 \%)$ managed by doctors.

\section{Discussion}

Evidence-based medicine has become a topic of debate in all fields of medicine. In this study, we surveyed the extent to which the activity of our accident and emergency department is evidence based.

This study demonstrated overall $90 \%$ of interventions were based on some scientific evidence as compared to $77 \%$ evidence-based interventions in the study by Lai et al. ${ }^{7}$ Our results were also comparable to similar studies conducted in other specialities. ${ }^{4-6,69}$ We found that two-thirds of interventions were based on the highest level of evidence and that routine practice in our unit is supported by good quality of evidence. Using similar classification, Kingston et $a l^{8}$ in a retrospective audit, found that $45 \%$ of interventions in surgical practice were based on randomised-controlled trials or better evidence. Lai et al, ${ }^{7}$ used same classification in a prospective audit and found that $42.9 \%$ of their patient intervention in ophthalmology was based on evidence from randomised-controlled trial or better. Our results were better than their study because of a different case mix and a guideline-based practice among NPs. Also, about half of the cases were common and simple, which were supported by a higher level of evidence. Moreover, historically Wolverhampton and Midland counties Eye Infirmary accident and emergency department provides an open, walk-in access for secondary and tertiary care to a large catchment area and hence there is a higher proportion of common and simple conditions presenting to us. Ellis et al ${ }^{4}$ used a different classification and reported that $53 \%$ of interventions in general medicine were based on randomised-controlled trials. Jemec et $a l^{5}$ 
Table 3 Interventions based on randomised controlled trials $(n=181)$

\begin{tabular}{|c|c|c|c|c|c|}
\hline Primary diagnosis & Primary intervention & $\begin{array}{l}\text { Total no. of } \\
\text { patients }\end{array}$ & $\begin{array}{l}\text { No. of patients } \\
\text { managed by } \\
\text { NPs }\end{array}$ & $\begin{array}{c}\text { No. of patients } \\
\text { managed by } \\
\text { doctors }\end{array}$ & Reference \\
\hline External eye foreign body & $\begin{array}{l}\text { Removal of foreign body, broad- } \\
\text { spectrum antibiotics, no patching }\end{array}$ & 84 & 84 & 0 & 16 \\
\hline Anterior uveitis & Topical steroids & 27 & 0 & 27 & 17 \\
\hline Dry eyes (moderate) & Viscotears & 28 & 28 & 0 & 18 \\
\hline Allergic conjunctivitis & G Opticrom & 5 & 2 & 3 & 19 \\
\hline Presumed viral conjunctivitis & Tear supplements & 4 & 4 & 0 & 20 \\
\hline Herpes zoster ophthalmicus & Oral acyclovir & 4 & 0 & 4 & 21 \\
\hline Proliferative diabetic retinopathy & $\begin{array}{l}\text { Argon laser panretinal } \\
\text { photocoagulation }\end{array}$ & 3 & 0 & 3 & 22 \\
\hline Severe keratoconjunctivitis sicca & G celluvisc & 3 & 0 & 3 & 23 \\
\hline Dry eyes (mild) & G hypotears & 4 & 4 & 0 & 24 \\
\hline Allergic rhinoconjunctivitis & Oral antihistamine & 3 & 3 & 0 & 25 \\
\hline Marginal keratitis & Topical steroid-antibiotic & 2 & 0 & 2 & 26 \\
\hline Corneal ulcer & $\begin{array}{l}\text { Corneal scrapes }+ \text { topical } \\
\text { ofloxacin }\end{array}$ & 2 & 0 & 2 & 27 \\
\hline Herpes zoster keratouveitis & Occ acyclovir + topical steroid & 1 & 0 & 1 & 28 \\
\hline Uveitis (steroid responder) & G vexol & 1 & 0 & 1 & 29 \\
\hline Allergic conjunctivitis & G Otrivine-antistin & 1 & 1 & 0 & 30 \\
\hline Allergic conjunctivitis & G Optilast & 1 & 0 & 1 & 31 \\
\hline $\begin{array}{l}\text { Congenital blocked nasolacrimal } \\
\text { duct }\end{array}$ & $\begin{array}{l}\text { Topical antibiotic }+ \text { hydrostatic } \\
\text { sac massage }\end{array}$ & 1 & 0 & 1 & 32 \\
\hline Blepharitis & Topical maxitrol & 1 & 0 & 1 & 33 \\
\hline Blepharits & Topical ofloxacin & 1 & 0 & 1 & 34 \\
\hline Ocular hypertension & Investigate & 1 & 0 & 1 & 35 \\
\hline Optic neuritis & MRI scan & 1 & 0 & 1 & 36 \\
\hline Retinal detachment & $\begin{array}{l}\text { Pars plana } \\
\text { vitrectomy }+ \text { encircling }+ \text { SF6 }\end{array}$ & 1 & 0 & 1 & 37 \\
\hline Exudative AMD & Fundus flourecein angiography & 1 & 0 & 1 & 38 \\
\hline Large choroidal melanoma & Enucleation & 1 & 0 & 1 & 39 \\
\hline
\end{tabular}

Table 4 Interventions based on prospective case series $(n=65)$

\begin{tabular}{|c|c|c|c|c|c|}
\hline Primary diagnosis & Primary intervention & $\begin{array}{l}\text { Total no. of } \\
\text { patients }\end{array}$ & $\begin{array}{c}\text { No. of patients } \\
\text { managed by } \\
\text { NPs }\end{array}$ & $\begin{array}{c}\text { No. of patients } \\
\text { managed by } \\
\text { doctors }\end{array}$ & Reference \\
\hline Meibomian cyst & $\begin{array}{l}\text { Topical antibiotics + warm } \\
\text { compresses }\end{array}$ & 23 & 23 & 0 & 40 \\
\hline Posterior vitreous detachment & $\begin{array}{l}\text { Full peripheral retinal } \\
\text { examination }+\mathrm{RD} \text { warning }+ \text { no } \\
\text { follow-up }\end{array}$ & 15 & 0 & 15 & 41 \\
\hline Marginal keratitis & Topical antibiotics & 5 & 3 & 2 & 42 \\
\hline $\begin{array}{l}\text { Corneal infiltrates in contact lens } \\
\text { wearers }\end{array}$ & Topical antibiotics & 4 & 4 & 0 & 43 \\
\hline Blepharitis & Lid hygiene & 3 & 3 & 0 & 44 \\
\hline Corneal ulcer & Topical antibiotics & 3 & 2 & 1 & 42 \\
\hline Meibomian cyst & Incision and curettage & 3 & 3 & 0 & 40 \\
\hline Loose corneal sutures & $\begin{array}{l}\text { Removal of sutures + topical } \\
\text { antibiotics }\end{array}$ & 2 & 0 & 2 & 45 \\
\hline $\begin{array}{l}\text { Intolerance to glaucoma } \\
\text { medication }\end{array}$ & Discontinue medication & 3 & 0 & 3 & 46 \\
\hline Corneal decompensation & Topical hypertonic saline & 1 & 0 & 1 & 47 \\
\hline Filamentary keratitis & Debridement of corneal filaments & 1 & 0 & 1 & 48 \\
\hline $\begin{array}{l}\text { Conjunctival reaction to vicryl, } \\
\text { recent squint surgery }\end{array}$ & Topical steroids & 1 & 0 & 1 & 49 \\
\hline Involutional entropion & Lateral canthal tendon strip & 1 & 0 & 1 & 50 \\
\hline
\end{tabular}


Table 5 Interventions based on retrospective case series $(n=42)$

\begin{tabular}{|c|c|c|c|c|c|}
\hline Primary diagnosis & Primary intervention & $\begin{array}{c}\text { Total no. of } \\
\text { patients }\end{array}$ & $\begin{array}{l}\text { No. of patients } \\
\text { managed by } \\
\text { NPs }\end{array}$ & $\begin{array}{l}\text { No. of patients } \\
\text { managed by } \\
\text { doctors }\end{array}$ & Reference \\
\hline Chemical conjunctivitis & Irrigation + topical antibiotics & 8 & 6 & 2 & 51 \\
\hline Posterior vitreous detachment & $\begin{array}{l}\text { Full peripheral retinal } \\
\text { examination }+\mathrm{RD} \\
\text { warning }+ \text { subsequent } \\
\text { assessment }\end{array}$ & 5 & 0 & 5 & 52 \\
\hline Episcleritis & Topical steroids & 5 & 0 & 5 & 53 \\
\hline Recurrent corneal erosion & Viscotears + lacrillube $\times 6 / 12$ & 4 & 4 & 0 & 54 \\
\hline Chemical conjunctivitis & Topical antibiotics & 4 & 4 & 0 & 51 \\
\hline Preseptal cellulites & Oral antibiotics & 2 & 0 & 2 & 55 \\
\hline $\begin{array}{l}\text { Wound abscess following lid } \\
\text { surgery }\end{array}$ & $\begin{array}{l}\text { Removal of infected } \\
\text { suture }+ \text { antibiotic }\end{array}$ & 1 & 0 & 1 & 56 \\
\hline Epscleritis & Oral anti-inflammatory & 1 & 1 & 0 & 53 \\
\hline Acute dacryocystitis & $\begin{array}{l}\text { Oral antibiotics + incision and } \\
\text { drainage }\end{array}$ & 1 & 0 & 1 & 57 \\
\hline Acute dacryocystitis & Oral antibiotics & 1 & 0 & 1 & 58 \\
\hline Secondary glaucoma & $\begin{array}{l}\text { Max medical therapy }+ \text { topical } \\
\text { steroids }\end{array}$ & 1 & 0 & 1 & 59 \\
\hline HSV Keratitis + sec raised IOP & Occ Zovirax + g timolol & 1 & 0 & 1 & 60 \\
\hline Blebitis & Topical antibiotics + steroids & 1 & 0 & 1 & 61 \\
\hline Sixth nerve palsy & Fresnel prism & 1 & 0 & 1 & 62 \\
\hline $\begin{array}{l}\text { Vertical diplopia (thyroid eye } \\
\text { disease) }\end{array}$ & Fresnel prism & 1 & 0 & 1 & 62 \\
\hline Third nerve palsy in infant & $\begin{array}{l}\text { Neurological evaluation }+ \text { MRI } \\
\text { scan }\end{array}$ & 1 & 0 & 1 & 63 \\
\hline Horseshoe retinal tear & Argon laser retinopexy & 1 & 0 & 1 & 64 \\
\hline Introcular foreign body & Removal of IOFB + vitrectomy & 1 & 0 & 1 & 65 \\
\hline $\begin{array}{l}\text { Nonarteritic anterior ischaemic } \\
\text { optic neuropathy }\end{array}$ & Oral aspirin & 1 & 0 & 1 & 66 \\
\hline Amaurosis fugax & Carotid doppler & 1 & 0 & 1 & 67 \\
\hline
\end{tabular}

Table 6 Interventions against evidence $(n=24)$

\begin{tabular}{|c|c|c|c|c|c|}
\hline Primary diagnosis & Primary intervention & $\begin{array}{l}\text { Total no. of } \\
\text { patients }\end{array}$ & $\begin{array}{c}\text { No. of patients } \\
\text { managed by } \\
\text { NPs }\end{array}$ & $\begin{array}{c}\text { No. of patients } \\
\text { managed by } \\
\text { doctors }\end{array}$ & Reference \\
\hline Presumed viral conjunctivitis & Topical antibiotics & 8 & 8 & 0 & 20 \\
\hline Rust ring & $\begin{array}{l}\text { Removal of rust with hypodermic } \\
\text { needle }\end{array}$ & 7 & 7 & 0 & 68 \\
\hline Corneal abrasion & Topical antibiotic + patching & 6 & 6 & 0 & 10 \\
\hline Herpes zoster ophthalmicus & Occ acyclovir & 1 & 0 & 1 & 21 \\
\hline $\begin{array}{l}\text { Presumed viral conjunctivitis, } \\
\text { PEH: corneal graft }\end{array}$ & Topical steroids & 1 & 0 & 1 & 20 \\
\hline Blepharitis & Topical steroids & 1 & 0 & 1 & 33 \\
\hline
\end{tabular}

in a retrospective study, reported that $38 \%$ of dermatologic therapeutic decisions were based on randomised-controlled trials. Myles et $a^{71}$ prospectively surveyed anaesthetic interventions in routine practice and found that $32 \%$ were supported by randomisedcontrolled trials.

Our study also highlighted the success of advanced role of trained NPs in acute ophthalmology. In 1998, Banerjee et $a l^{70}$ carried out a study to assess the diagnostic and management skills of eye-dedicated NPs. They found $100 \%$ concordance between NPs and supervising doctor in diagnosis and $96 \%$ concordance between the two in management of those cases. In our accident and emergency department, NPs routinely treat and discharge cases like conjunctivitis, corneal abrasion, recurrent corneal erosion, dry eyes, external eye foreign body, meibomian cyst, etc. These conditions form the major bulk of acute ophthalmology. There are guidelines 
Table 7 Interventions in which no evidence was found $(n=22)$

\begin{tabular}{|c|c|c|c|c|}
\hline Primary diagnosis & Primary intervention & $\begin{array}{l}\text { Total no. of } \\
\text { patients }\end{array}$ & $\begin{array}{l}\text { No. of patients } \\
\text { managed by } \\
\text { NPs }\end{array}$ & $\begin{array}{l}\text { No. of patients } \\
\text { managed by } \\
\text { doctors }\end{array}$ \\
\hline Traumatic conjunctival laceration & Topical antibiotic & 7 & 0 & 7 \\
\hline $\begin{array}{l}\text { Traumatic subconjunctival } \\
\text { haemorrhage }\end{array}$ & Topical antibiotic & 3 & 3 & 0 \\
\hline $\begin{array}{l}\text { Acute nonarteritic central retinal } \\
\text { artery occlusion }\end{array}$ & $\begin{array}{l}\text { Ocular massage, } \mathrm{CO}_{2} \text { rebreathing, } \\
\text { IV Diamox, tab aspirin, } \\
\text { cardiovascular investigation }\end{array}$ & 2 & 0 & 2 \\
\hline Allergy to cosmetic product & Avoid allergen & 2 & 2 & 0 \\
\hline Episcleritis & G acular & 2 & 0 & 2 \\
\hline Herpes zoster ophthalmicus & Occ chloramphenicol & 1 & 1 & 0 \\
\hline Dendritic ulcer & Occ chloramphenicol & 1 & 1 & 0 \\
\hline Filamentary keratitis & Occ chloramphenical & 1 & 1 & 0 \\
\hline $\begin{array}{l}\text { Traumatic subconjunctival } \\
\text { haemorrhage }\end{array}$ & $G$ viscotears & 1 & 1 & 0 \\
\hline Inflammed pingencula & Topical antibiotic & 1 & 1 & 0 \\
\hline Conjunctival retention cyst & Topical lubricant & 1 & 1 & 0 \\
\hline
\end{tabular}

and protocols drawn up for management of conditions like conjunctivitis, corneal abrasion, and external eye foreign body from evidence provided from systematic review and meta-analysis of various studies. There is also a care pathway for conjunctivitis in practice which provides an evidence-based approach for management of acute bacterial, viral or allergic conjunctivitis. Hence, the higher proportion of interventions based on levels 1, 2, and 3 evidence among the patients managed by NPs.

This study shows that the number of patient interventions based on highest level of evidence was higher in NPs' group than ophthalmologists. As mentioned earlier, NPs were involved in managing common and relatively simpler conditions like external eye foreign body, presumed bacterial conjunctivitis, corneal abrasion, and dry eyes. There were 218 patients with these four diagnoses that formed $70.8 \%$ of NPs practice and four out of 32 diagnosis-intervention pairs based on levels 1, 2, and 3 evidence. This is also based on our local protocol which encourages NPs to manage such conditions that are simpler to manage and are backed by the highest level of evidence.

Tables 2-7 show the wide range of ophthalmic emergencies that are presented in our casualty department during the study period. As mentioned earlier, all common and routine cases are routinely dealt with by trained NPs and the rest by the ophthalmologists. Some of the cases managed by the ophthalmologists tend to be complex thus explaining the relatively lower percentage of patients managed on higher levels of evidence by the ophthalmologists as compared to the NPs. In all, $51.1 \%$ of interventions by ophthalmologists were based on the highest level of evidence, that is, systematic review, meta-analysis, and randomised-controlled trials, which was comparable with other studies. ${ }^{4-8,69}$

Critics of evidence-based medicine argue that it relies heavily on randomised-controlled trials. There are some interventions that can never be supported by randomised-controlled trials. Conditions such as nonarteritic central retinal artery occlusion are rare and it is difficult to set up a randomised-controlled trial to prove the benefit of a particular method of treatment. However, as the authors of the Cochrane review suggest, as the sight loss can be devastating, it is understandable to try simple noninvasive treatments so that both parties can feel that 'something was done' ${ }^{71}$ For the management of conditions such as chemical conjunctivitis, preseptal cellulitis, acute dacryocystitis, etc, natural history and long-term follow-up studies provide valid evidence and it would be difficult to carry out randomised-controlled trials. However, there is a need for stronger evidence to manage conditions like posterior vitreous detachment, marginal keratitis, recurrent corneal erosion, etc.

There are certain limitations to our study which need to be addressed. We included any randomised-controlled trial as a higher level of evidence to any prospective or retrospective study. An ill-designed randomisedcontrolled trial with short follow-up can give less valid evidence as compared to a long-term follow-up study. Owing to the large scale of our study, it was not possible to look at the validity of individual studies. Another shortcoming was that we searched only two databases, that is, Medline and Cochrane database and our search was limited to English language. Hence, there is a possibility that we might have missed studies cited on other database and also published in other language. 
In summary, our study demonstrated that a majority of our practice in acute ophthalmology is based on scientific evidence. This study has also highlighted potential areas for future research.

\section{References}

1 Sackett DL, Rosenberg WC, Muir Gray JA, Haynes RB, Richardson WS. Evidence-based medicine: what it is and what it isn't. BMJ 1996; 312: 71-72.

2 Phillips B, Ball C, Sackett D, Badenoch D, Straus S, Haynes B et al. Oxford centre of evidence-based medicine levels of evidence. November 1998,. http://www.cebm.net/ levels_of_evidence.asp.

3 Smith R. Where is wisdom...? The poetry of medical evidence. BMJ 1991; 303: 798-799.

4 Ellis J, Mulligan I, Rowe J, Sackett DL. Inpatient general medicine is evidence based. Lancet 1995; 346: 407-410.

5 Jemec GB, Thorsteinsdittir H, Wulf HC. Evidence-based dermatologic out-patient treatment. Int J Dermatol 1998; 37: 850-854.

6 Howes N, Chagla L, Thorpe M, McCulloch P. Surgical practice is evidence based. Br J Surg 1997; 84: 1220-1223.

7 Lai TYY, Wong VWY, Leung GM. Is ophthalmology evidence based? A clinical audit of emergency unit of a regional eye hospital. Br J Ophthalmol 2003; 87: 385-390.

8 Kingston R, Barry M, Tierney S, Drumm J, Grace P. Treatment of surgical patients is evidence-based. Eur J Surg 2001; 167: 324-330

9 Sheikh A, Hurwitz B, Cave J. Antibiotics versus placebo for acute bacterial conjunctivitis (Cochrane Review). In: The Cochrane Library, Issue 2, Chichester, UK: John Wiley \& Sons, Ltd, 2004.

10 Flynn CA, D'Amico F, Smith J. Should we patch corneal abrasions? A meta-analysis. J Fam Pract 1998; 47: 264-270.

11 Wilhelmus KR. Interventions for herpes simplex virus epithelial keratitis (Cochrane Review). In: The Cochrane Library, Issue 2, Chichester, UK: John Wiley \& Sons, Ltd, 2004.

12 Snellingen T, Evans JR, Ravilla T, Foster A. Surgical interventions for age-related cataract (Cochrane Review). In: The Cochrane Library, Issue 2, Chichester, UK: John Wiley \& Sons, Ltd, 2004.

13 Wilkinson C. Interventions for asymptomatic retinal breaks and lattice degeneration for preventing retinal detachment (Cochrane Review). In: The Cochrane Library, Issue 2, Chichester, UK: John Wiley \& Sons, Ltd, 2004.

14 Sivak-Callcott JA, O'Day DM, Gass DM, Tsai JC. Evidencebased recommendations for the diagnosis and treatment of Neovascular glaucoma. Ophthalmology 2001; 108: 1767-1778.

15 Seregard S. Long-term survival after ruthenium plaque radiotherapy for uveal melanoma. A meta-analysis of studies including 1,066 patients. Acta Ophthalmology Scand 1999; 77(4): 414-417.

16 Kaiser PK. A comparison of pressure patching versus no patching for corneal abrasions due to trauma or foreign body removal. Corneal Abrasion Patching Study Group. Ophthalmology 1995; 102: 1936-1942.

17 Dunne JA, Travers JP. Double-blind clinical trial of topical steroids in anterior uveitis. Br J Ophthalmol 1979; 63: 762-767.
18 Sullivan LJ, McCurrach F, Lee S, Taylor HR, Rolando M, Marechal-Courtois C et al. Efficacy and safety of $0.3 \%$ carbomer gel compared to placebo in patients with moderate-to-severe dry eye syndrome. Ophthalmology 1997; 104(9): 1402-1408.

19 Leino M, Ennervaara K, Latvala AL, Nordgren P, Posti AM, Suves R et al. Double-blind group comparative study of $2 \%$ nedocromil sodium eye drops with $2 \%$ sodium cromoglycate and placebo eye drops in treatment of seasonal allergic conjunctivitis. Clin Exp Allergy 1992; 22: 929-932.

20 Ward JB, Siojo LG, Waller SG. A prospective, masked clinical trial of trifluridine, dexamethasone and artificial tears in the treatment of epidemic keratoconjunctivitis. Cornea 1993; 12(3): 216-221.

21 Neoh C, Harding SP, Saunders D, Wallis S, Tullo AB, Nylander A et al. Comparison of topical and oral acyclovir in early herpes zoster ophthalmicus. Eye 1994; 8(part 6): 688-691.

22 Early photocoagulation for diabetic retinopathy. ETDRS report number 9. Early Treatment Diabetic Retinopathy Study Research Group. Ophthalmology 1991; 98(5 Suppl): 766-785.

23 Grene RB, Lankston P, Mordaunt J, Harrold M, Gwon A, Jones R. Unpreserved carboxymethylcellulose artificial tears evaluated in patients with keratoconjunctivitis sicca. Cornea 1992; 11(4): 294-301.

24 Norn MS. Treatment of keratoconjunctivitis sicca with liquid paraffin or polyvinyl alcohol in double-blind trial. Acta Ophthalmol (Copenh) 1977; 55(6): 945-950.

25 Juniper EF, Guyatt GH, Ferrie PJ, Griffith LE. First-line treatment of seasonal (ragweed) rhinoconjunctivitis. A randomised management trial comparing a nasal steroid spray and a non sedating antihistamine. Can Med Assoc J 1997; 156: 1123-1131.

26 Chignell AH, Easty DL, Chesterton JR, Thomsitt J. Marginal ulceration of the cornea. Br J Opthalmol 1970; 54(7): 433-440.

27 Prajna NV, George C, Selvaraj S, Lu KL, McDonnell PJ, Srinivasan M. Bacteriologic and clinical efficacy of oflaxacin $0.3 \%$ versus ciprofloxacin $0.3 \%$ ophthalmic solutions in the treatment of patients with culture-positive bacterial keratitis. Cornea 2001; 20: 175-178.

28 McGill J, Chapman C. A comparison of topical acyclovir with steroids in the treatment of herpes zoster keratouveitis. Br J Ophthalmol 1983; 67(11): 746-750.

29 Foster CS, Alter G, DeBarge LR, Raizman MB, Crabb JL, Santos CI et al. Efficacy and safety of rimexolone $1 \%$ ophthalmic suspension vs $1 \%$ prednisolone acetate in the treatment of uveitis. Am J Ophthalmol 1996; 122(2): 171-182.

30 Lanier BQ, Tremblay N, Smith JP, deFaller JM. A doublemasked comparison of ocular decongestants as therapy for allergic conjunctivitis. Ann Allergy 1983; 50: 174-177.

31 Friedlaender MH, Harris J, LaVallee N, Russell H, Shilstone $\mathrm{J}$. Evaluation of the onset and duration of effect of azelastine eye drops $(0.05 \%)$ versus placebo in patients with allergic conjunctivitis using an allergen challenge model. Ophthalmology 2000; 107: 2152-2157.

32 Kushner BJ. Congenital nasolacrimal system obstruction. Arch Ophthalmol 1982; 100(4): 597-600.

33 Shulman DG, Sargent JB, Stewart RH, Mester U. Comparative evaluation of the short-term bactericidal potential of a steroid-antibiotic combination versus steroid in the treatment of chronic bacterial blepharitis and conjunctivitis. Eur J Ophthalmol 1996; 6: 361-367. 
34 Bron AJ, Leber G, Rizk SN, Baig H, Elkington AR, Kirkby $\mathrm{GR}$ et al. Ofloxacin compared with chloramphenicol in the management of external ocular infection. Br J Ophthalmol 1991; 75(11): 675-679.

35 Kass MA, Heuer DK, Higginbotham EJ, Johnson CA, Keltner JL, Miller JP et al. The Ocular Hypertension Treatment Study: a randomized trial determines that topical ocular hypotensive medication delays or prevents the onset of primary open-angle glaucoma. Arch Ophthalmol 2002; 120(6): 701-713.

36 Beck RW, Trobe JD, Moke PS, Gal RL, Xing D, Bhatti MT et al. Optic Neuritis Study Group. High- and low-risk profiles for the development of multiple sclerosis within 10 years after optic neuritis: experience of the optic neuritis treatment trial. Arch Ophthalmol 2003; 121(7): 944-949.

37 Hammer M, Margo CE, Grizzard WS. Complex retinal detachment treated with silicone oil or sulfur hexafluoride gas: a randomised clinical trial. Ophthalmic Surg Lasers 1997; 28: 926-931.

38 Argon laser photocoagulation for neovascular maculopathy Five-year results from randomized clinical trials. Macular Photocoagulation Study Group. Arch Ophthalmol 1991; 109(8): 1109-1114.

39 The Collaborative Ocular Melanoma Study (COMS). Randomized trial of pre-enucleation radiation of large choroidal melanoma II: initial mortality findings. COMS report no. 10. Am J Ophthalmol 1998; 125(6): 779-796.

40 Jackson TL, Beun L. A prospective study of cost, patient satisfaction, and outcome of treatment of chalazion by medical and nursing staff. Br J Ophthalmol 2000; 84: 782-785.

41 Richardson PS, Benson MT, Kirkby GR. The posterior vitreous detachment clinic: do new retinal breaks develop in the six weeks following an isolated symptomatic posterior vitreous detachment? Eye 1999; 13(Part 2): 237-240.

42 Bennett HGB, Hay J, Kirkness CM, Seal DV, Devonshire P. Antimicrobial management of presumed microbial keratitis: guidelines for treatment of central and peripheral ulcers. $\mathrm{Br}$ J Ophthalmol 1998; 82: 137-145.

43 Stein RM, Clinch TE, Cohen EJ, Genvert GI, Arentsen JJ, Laibson PR. Infected vs sterile corneal infiltrates in contact lens wearers. Am J Ophthalmol 1988; 105: 632-636.

44 Key JE. A comparative study of eyelid cleaning regimens in chronic blepharitis. CLAO J 1996; 22: 209-212.

45 Heaven CJ, Davison CRN, Cockcroft PM. Bacterial contamination of nylon corneal sutures. Eye 1995; 9: 116-118.

46 Bhatt R, Whittaker KW, Appaswamy S, Desai A, Fitt A, Sandramouli S. Prospective survey of adverse reactions to antiglaucoma medications in a hospital population. Eye 2005; 19: 392-395.

47 Luxemberg MN, Green K. Reduction in corneal edema with topical hypertonic agents. Am J Ophthalmol 1971; 71: 847-853.

48 Arora I, Singhvi S. Impression debridement of corneal lesions. Ophthalmology 1994; 101: 1935-1940.

49 Helveston EM, Callahan MA. Synthetic absorbable suture for strabismus surgery. Am J Ophthalmol 1976; 82: 300-302.

50 Olver JM, Barnes JA. Effective small incision surgery for involutional lower lid entropion. Ophthalmology 2000; 107: 1982-1988.

51 Brodovsky SC, McCarty CA, Snibson G, Loughnan M, Sullivan L, Daniell M et al. Management of alkali burns: an 11-year retrospective review. Ophthalmology 2000; 107: 1829-1835.
52 Dayan MR, Jayamanne DGR, Andrews RM, Griffiths PG. Flashes and floaters as predictors of vitreoretinal pathology: is follow-up necessary for posterior vitreous detachment? Eye 1996; 10: 456-458.

53 Jabs DA, Mudun A, Dunn JP, Marsh MJ. Episcleritis and Scleritis: clinical features and treatment results. Am J Ophthalmol 2000; 130: 469-476.

54 Reidy JJ, Paulus MP, Gona S. Recurrent erosions of the cornea: epidemiology and treatment. Cornea 2000; 19(6): 767-771.

55 Sobol SE, Marchand J, Tewfik TL, Manoukian JJ, Schloss MD. Orbital complications of sinusitis in children. J Otolaryngol 2002; 31(3): 131-136.

56 Mehta P, Patel P, Olver JM. Functional results and complications of Mersilene mesh use for frontalis suspension ptosis surgery. Br J Ophthalmol 2004; 88(3): 361-364.

57 Cahill KV, Burns JA. Management of acute dacryocystitis in adults. Ophthalmol Plast Reconstr Surg 1993; 9(1): 38-41.

58 Huber-Spitzy V, Steinkogler FJ, Huber E, Arocker-Mettinger $\mathrm{E}$ et al. Acquired dacryocystitis: microbiology and conservative therapy. Acta Ophthalmol (Copenhagen) 1992; 70(6): 745-749.

59 Takashi T, Ohtani S, Miyata K, Miyata N, Shirato S, Mochizuki M. A clinical evaluation of uveitis-associated secondary glaucoma. Jpn J Ophthalmol 2002; 46: 556-562.

60 Falcon MG, Williams HP. Herpes simplex kerato-uveitis and glaucoma. Trans Ophthalmol Soc UK 1978; 98: 101-104.

61 Ciulla TA, Beck AD, Topping TM, Baker AS. Blebitis, early endophthalmitis, and late endophthalmitis after glaucomafiltering surgery. Ophthalmology 1997; 104: 986-995.

62 Flanders M, Sarkis N. Fresnel membrane prisms: clinical experience. Can J Ophthalmol 1999; 34: 335-340.

63 Tsaloumas MD, Willshaw HE. Congenital oculomotor palsy: associated neurological and ophthalmological findings. Eye 1997; 11: 500-503.

64 Pollack A, Oliver M. Argon laser photocoagulation of symptomatic flap tears and retinal breaks of fellow eyes. $\mathrm{Br} J$ Ophthalmol 1981; 65(7): 469-472.

65 Wani VB, Al-Ajmi M, Thalib L, Azad RV, Abdul M, AlGhanim $\mathrm{M}$ et al. Vitrectomy for posterior segment intraocular foreign bodies: visual results and prognostic factors. Retina 2003; 23(5): 654-660.

66 Salomon O, Huna-Baron R, Steinberg DM, Kurtz S, Seligsohn U. Role of aspirin in reducing the frequency of second eye involvement in patients with non-arteritic anterior ischaemic optic neuropathy. Eye 1999; 13: 357-359.

67 Mukherji S, Kurli M, Sandramouli S. Indications and outcome of carotid Doppler ultrasound: an ophthalmic perspective. Eur J Ophthalmol 2004; 14(3): 240-244.

68 Sigurdsson H, Hanna I, Lockwood AJ, Longstaff S. Removal of rust rings comparing electric drill and hypodermic needle. Eye 1987; 1: 430-432.

69 Myles PS, Bain DL, Johnson F, McMahon R. Is anaesthesia evidence-based? A survey of anaesthetic practice. $\mathrm{Br} J$ Anaesth 1999; 82: 591-595.

70 Banerjee S, Beatty S, Tyagi A, Kirkby GR. The role of ophthalmic triage and the nurse practitioner in an eye-dedicated casualty department. Eye 1998; 12: 880-882.

71 Fraser S, Siriwardena D. Interventions for acute nonarteritic central retinal artery occlusion (Cochrane Review). In: The Cochrane Library, Issue 2, Chichester, UK: John Wiley \& Sons, Ltd, 2004. 